\title{
The effect of a pratfall on increasing interpersonal attractiveness'
}

\author{
ELLIOT ARONSON, UNIVERSITY OF TEXAS
}

BEN WILLERMAN, SOCIAL SCIENCE RESEARCH COUNCIL JOANNE FLOYD, UNIVERSITY OF UTAH
An experiment was performed which demonstrated that the attractiveness of a superior person is cnhanced if he commits a clumsy blunder; the same blunder tends to decrease the the attractiveness of a mediocre person. We predicted these results by conjecturing that a superior person may be viewed as superhuman and, therefore, distant; a blunder tends to humanize him and, consequently, inc reases his attractiveness

If we assume that superior intellectual ability is a positive attribute and if we assume that people with positive attributes are more attractive than those with neutral or negative attributes, it seems obvious that, all other things being equal, we should like people of superior intellectual ability more than mediocre, average, or stupid people. Yet, obvious as this relationship may seem, it is not always the case. For example, it has been shown that group members who are considered the most able are not necessarily the best liked (Hollander \& Webb, 1955). It has also been demonstrated that people who initiate the most ideas and are acknowledged as the best "idea" men by other members of their group are usually not the best liked group members (Bales, 1953, 1955, 1958; Bales \& Slater, 1955).

The rejection of a person of high intellectual ability may be due to an incompatibility between proficiency in intellectual and social roles; i.e., individuals of high intellectual ability may be brusque or unpleasant interpersonally. What we are proposing is a totally different explanation for this phenomenon-one that involves intellectrual ability per se. A great deal of ability, in and of itself, might make the stimulus person seem "too good," unapproachable, distant, non-human. This might occur even if his social skills were the equal of his less able counterpart. If this were the case, some evidence of fallibility may raise the individual's attractiveness. A near perfect or superior individual who shows that he is capable of an occasional blunder or pratfall may come to be regarded as more human and more approachable; consequently, he will be liked better because of this pratfall. On the other hand, if a mediocre or average person commits an identical blunder, he will not undergo an increase in attractiveness. Indeed, since it would suggest only that he is very mediocre, it should lower his attractiveness. Consequently, we are predicting an interaction between ability and pratfall. Procedure

The Ss were 48 male sophomores recruited from an introductory psychology course at the University of
Minnesota. For the sake of economy, Ss were run in groups of two; they were separated by a cardboard screen and were not permitted to communicate in any way.

The general procedure involved having the $\mathrm{S}$ listen to one of four tape recordings of a stimulus person. On one tape the stimulus person was one of very high ability; on another he was a person of average ability. On a third tape the person of high ability committed a clumsy and embarrassing blunder; on a fourth tape the person of average ability committed an identical blunder. At the end of the tape each Swas interviewed and asked for his reactions to the stimulus person by one of two interviewers. The assignment of Ss to experimental condition and to the interviewer were randomly determined.

The experiment was described as a study of impression formation. Ss were told that they would be listening to a tape recording recently made of a student trying out for the College Quiz Bowl team. E informed the Ss that after hearing the tape they would be asked to state their impressions of the student. The tape was actually a contrived one in which the stimulus person was asked 50 difficult quiz questions. The tapes used in the four experimental conditions were identical except for manipulations of ability and pratfall.

Superior Ability: On two of the tapes the stimulus person answered $92 \%$ of the questions correctly. Furthermore, during an interview, he admitted (modestly) that, in high school, he had been an honor student, yearbook editor, and a member of the track team.

Average Ability: On two tapes the stimulus person answered only $30 \%$ of the questions correctly. During the interview he admitted that he received average grades in high school, was a proof-reader on the yearbook, and had tried out for the track team but failed to make it.

Pratfall: Near the end of the interview the stimulus person clumsily spilled a cup of coffee all over himself. On the tape this blunder was accompanied by a good deal of noise and clatter, the scraping of a chair, and the stimulus person's anguished statement, "Oh my goodness, I've spilled coffee all over my new suit." The coffee-spilling incident was taped, duplicated, and spliced onto one of the Superior Ability tapes and onto one of the Average Ability tapes. After the tape was played, E led $\mathrm{S}$ to one of two rooms, assigned him to one of two interviewers, and left the room. The interviewers, who were ignorant of S's experimental condition, asked $\mathrm{S}$ eight questions pertaining to his 
impressions of the stimulus person plus a few filler questions. As a check on the manipulation of ability, $S$ was also asked to rate the stimulus person's intelligence. $S$ answered each question orally and also indicated the intensity of his feeling on a scale ranging from -7 to +7 .

\section{Results and Discussion}

The results indicate that the manipulation of ability was successful; Ss in the Superior Ability conditions rated the stimulus person more intelligent $(M=5.73)$ than in the Average Ability conditions $(M=0.83 ; t=6.89$, $\mathrm{p}<.005)$.

A composite attractiveness score was computed for each $S$ by summing the numerical responses given to the eight interview questions assessing the $S^{\prime} S$ attraction to the stimulus person. Table 1 lists the mean attraction scores by experimental condition. Inspection of Table 1 shows that the most attractive stimulus person was the superior person who committed a blunder $(M=30.2)$ while the least attractive stimulus person was the average person who committed a blunder ( $M=-2.5$ ). The data were analyzed by analysis of variance. There was a significant effect due to ability-Ss indicated a greater liking for the Superior Ability person than the Average Ability person $(F=14.90$, $\mathrm{df}=1 / 40, \mathrm{p}<.001$ ). This main effect must be qualified by a significant interaction between ability and pratfall ( $F=10.33$, df $=1 / 40, p<.01$ ). The pratfall had the effect of increasing the liking the $S$ had for the person of superior ability while the same pratfall decreased his liking for the person of average ability. These results confirmed our hypothesis. The effect of the pratfall, by itself, was insignificant. There were no significant interviewer effects.

Thus, within the range of ability varied in this experiment, higher ability leads to greater attractiveness;

Table 1. Mean Attraction Scores

\begin{tabular}{lcc} 
& Protfall & No Pratfall \\
\hline Superior Ability & 30.2 & 20.8 \\
Average Ability & -2.5 & 17.8 \\
\hline
\end{tabular}

however, the pratfall does not have this uniform effect. Whether a pratfall increases or decreases the attractiveness of a person depends upon the level of his ability. A contrast comparing the difference between the Pratfall and the No Pratfall conditions within the Superior Ability $\left(\mathrm{M}_{\mathrm{D}}=+9.4\right)$ condition and within the Average Ability $\left(\mathrm{M}_{\mathrm{D}}=-20.3\right)$ condition is highly significant in the predicted direction $(t=3.18, p<.005)$. Furthermore, separate contrasts for the Superior and Average Ability conditions lend additional support to the hypothesis. In the Average Ability-No Pratfall condition the stimulus is rated as significantly more attractive than in the Average Ability-Pratfall condition $(t=3.15, p<.01)$. However, the comparison between the Superior AbilityPratfall and Superior Ability-No Pratfall conditions, while in the expected direction, does not reach statistical significance $(t=1.45, p<.18)$.

Taken as a whole, these data support the contention that a blunder on the part of a superior person removes the onus of being "too good"'; it increases his approachability and makes him seem less austere, more human-while a blunder on the part of a mediocre person makes him seem that much more mediocre.

\section{References}

Bales, R. F. The equilibrium problem in small groups. In $T$. Parsons, R. F. Bales, \& E. A. Shils (Eds.), Working papers in the theory of action. Glencoe, Ill.: The Free Press, 1953. Pp. 111-161.

Bales, R. F. How people interact in conferences. Scient. American, $1955,192,31-35$.

Bales, R. F. Task roles and social roles in problem solving groups. In Eleanor E. Maccoby, T. M. Newcomb, \& E. L. Hartley (Eds.), Readings in Social Psychology (3rd Ed.). New York: Holt, 1958. Pp. 437-447.

Bales, R. F., \& Slater, P. E. Role differentiation in small decision-making groups. In T. Parson, R. F. Bales, et al (Eds.), The family, socialization, and interaction process. New York: Free Press, 1955. Pp. 259-306.

Hollander, E. P., \& Webb, W. B. Leadership, followership, and friendship: An analysis of peer nominations. J. abnorm. soc. Psychol., 1955, 50, 163-167.

\section{Note}

1. This research was supported by grants from the National Science Foundation (NSF GS 202 and NSF GS 750) to Elliot Aronson and was carried out at the University of Minnesota.

\section{Comment on Murray and Kohfeld by Robert Adamson}

Murray \& Kohfeld (1965) interpret stimulus intensity dynamism in terms of the relation between pre-test $A L$ and test signal intensities. An alternative assumption is made about the AL for one of their groups, and a reinterpretation of their findings is offered which incorporates a tension level intermediary between the aforementioned relationship and performance.

Results reported by Murray \& Kohfeld (1965) in a study pertaining to stimulus intensity dynamism are consonant with those reported in earlier studies on reinforcement effects (Bevan \& Adamson, 1960; Black, Adamson, \& Bevan, 1961) which also utilized an adapta- tion level model. An alternative interpretation of the results is suggested, however, if a different assumption is made about one of the groups in the study.

Murray and Kohfeld pre-adapted three groups, respectively, to $40 \mathrm{db}$ tones, $100 \mathrm{db}$ tones, and silence (presumably, about $10 \mathrm{db}$ ). They tested reaction time (RT) for the groups to randomized presentation of auditory signals having a geometric mean of $70 \mathrm{db}$. "It was anticipated that the effective AL during RT trials would be near 40 or $100 \mathrm{db}$ for Ss initially adapted at those levels and near the geometric mean of the test intensities $(70 \mathrm{db})$ for Ss adapted to silence. Thus it was expected that mean RTs at all levels of signal intensity would be 